\title{
Analysis of conditional gene deletion using probe based Real-Time PCR
}

Britta Weis ${ }^{1 *}$, Joachim Schmidt ${ }^{2}$, Frank Lyko ${ }^{1}$, Heinz G Linhart ${ }^{3}$

\author{
Abstract \\ Following publication of this article [1] the authors noticed that an incorrect probe reference was cited on page 3, \\ 4, 5 and 6 ("UP \#69, Roche Applied Science"). The correct probe that was used for the 1lox/2lox allele ratio analysis \\ in the paper is as follows \\ Probe for 1 lox/2lox allele quantification: \\ 5'-6-FAM-atAaCtTCgtatagCATaCattatac-BHQ-1 -3' \\ (uppercase letters $=$ LNA bases) \\ Manufacturer: EUROGENTEC, Seraing, Belgium \\ All other information and reaction conditions in the paper are correct as stated.
}

\begin{abstract}
Author details
'Division of Epigenetics, German Cancer Research Center, Heidelberg, Germany. ${ }^{2}$ Division of Translational Oncology, German Cancer Research

Center, Heidelberg, Germany. ${ }^{3}$ Department of Gastroenterology and Hepatology, University Hospital Freiburg, Hugstetter Str. 49, 79106 Freiburg,

Germany.
\end{abstract}

Received: 13 December 2010 Accepted: 21 December 2010

Published: 21 December 2010

\section{Reference}

1. Weis B, Schmidt J, Lyko F, Linhart HG: Analysis of conditional gene

deletion using probe based Real-Time PCR. BMC Biotechnology 2010 10:75.

doi:10.1186/1472-6750-10-90

Cite this article as: Weis et al:: Analysis of conditional gene deletion using probe based Real-Time PCR. BMC Biotechnology 2010 10:90.

*Correspondence: b.weis@Dkfz-Heidelberg.de

'Division of Epigenetics, German Cancer Research Center, Heidelberg,

Germany

Full list of author information is available at the end of the article

Submit your next manuscript to BioMed Central and take full advantage of:

- Convenient online submission

- Thorough peer review

- No space constraints or color figure charges

- Immediate publication on acceptance

- Inclusion in PubMed, CAS, Scopus and Google Scholar

- Research which is freely available for redistribution 